\title{
ANATOMICALLY PRESERVED MIOCENE FERNS FROM THE YAKIMA CANYON IN CENTRAL WASHINGTON STATE
}

ARNONE*, Elyssa A.; ROTHWELL, Gar W., Department of Environmental and Plant Biology, Ohio University, Athens $\mathrm{OH}$ 45701, U.S.A.; PIGG, Kathleen B., Department of Botany, Arizona State University, Tempe AZ 85287, U.S.A.

Several filicalean ferns occur in permineralized peat surrounding the bases of silicified tree trunks that are preserved in the Yakima basalts between Yakima and Ellensburg, Washington. The plants were apparently growing in shallow lakes or swamps during deposition of the Miocene Yakima Basalts. The osmundaceous fern Osmunda wehrii Miller was previously described from stems and petiole bases. Our material consists of several such plant bases, but also includes abundant foliar fragments that are pinnately compound and have pinnules with anastomosing veins.

Smaller, rhizomatous filicalean ferns are also represented in the peats by stems and frond bases. Rhizomes extend horizontally through the matrix, branching at intervals and forming mats of fern material. Rhizomes range up to $1 \mathrm{~cm}$ in diameter, are amphiphloic and dictyostelic, and often display a ring of hypodermal fibers. Some specimens have paired leaf traces similar to the Aspleniaceae-type of Ogura, and resemble some species of Dryopteris. Other ferns appear to have several terete bundles that form a C-shaped arc at the base of the leaf. These latter specimens resemble some species of Polypodium and possibly Elaphoglossum, and demonstrate that modern filicaleans were characteristic of the Miocene vegetation of western North America. 